\title{
Peran Stasiun Televisi dalam Pengembangan Demokrasi, Ekonomi dan Politik di Indonesia
}

\section{The Role Of Television Station In The Development Of Democracy, Economic And Political In Indonesian}

\author{
Subhan AB \\ Universitas Gajah Putih Takengon, Indonesia \\ *Email: subhanab@yahoo.co.id
}

\begin{abstract}
Abstrak
Dewasa ini televisi, sebagai bagian dari komunikasi massa di asumsikan memegang posisi penting dalam masyarakat. Peranan penting televise telah menjadikan media ini berkembang pesat dalam 20 tahun ini. Televisi hadir sebagai alat sosial, politik, budaya, bahkan sebagai sebuah industri informasi dari sebuah perusahaan. Sebagai industri, televisi menjanjikan keuntungan cukup besar bagi pemiliknya, bersaing secara kompetitif.Kini televisi tidak lagi menjadi media yang berorientasi untuk memenuhi kebutuhan masyarakat dalam hal informasi dan hiburan yang sehat, melainkan lebih dominan pada keuntungan ekonomi kapitalis, kekuatan pasar secara kompetitif. Dampaknya masyarakat 'kering' informasi yang ditampilkan secara both of side dan aktual. Pemberitaan media televisi dikemas sedemikian rupa dengan metode agenda setting. Hal ini menjadi dilematis tersendiri bagi para penggiat jurnalistik: antara publik atau kepentingan pemilik? Berita-berita yang disajikan dan ditayangkan oleh media televisi lebih berorientasi kepada pentingan pemilik, bukan kepentingan publik. Sementara itu, kapitalisasi dalam industri media televisi terus menggurita. Ada pemilik tunggal untuk beberapa stasiun televisi yang menyalahi regulasi dari penyiaran di Indonesia. Kendati sudah diatur sedemikian baiknya, namun konglomerasi dalam industri pertelevisian di Indonesia belum dibenahi. Politik dan ekonomi menjadi alasan utama sehingga regulasi penyiaran di Indonesia belum mampu diterapkan seperti di Eropa dan Amerika Serikat.
\end{abstract}

Kata Kunci: Media, Televisi, Industri Media, Regulasi, Politik dan Ekonomi

\begin{abstract}
In the recent times television, as a part of the mass communication uprising in assume holding the pivotal position in the community.The important role of television has made the media growing fast in 20 years.Television attended the dialogue as an instrument social, political, culture, even as an industry fights against information of this kind from a public social security agency.As industry, television promises a profit quite big advantage to the owner of the land, suddenly find themselves in competition in the manner of a competitive since it creates substantial .The navy was scouring the television is no longer to be the medium that is oriented to meet the people needs in terms of information and an education, but as something more dominant at a profit a capitalist economy, the power of the market as competitive since it creates substantial.The impact of their absence the community dry the information displayed by the indonesian government security officer of new england electric both side and actual.The way of the spread the media television packed in such a way as with the methods the agenda for a look at a.This can be traced to by themselves each with an becomes a dilemma health providers available for its penggiat journalistic: between public or the interests of the owner of ?Berita-berita who is served and was being broadcast by the media television are more oriented towards to pentingan the owner of, is not the benefit of the public.Meanwhile, capitalization in industry television continue to menggurita.Is the sole owner of for some the tv station break regulations of broadcasting in indonesia.Even though he had arranged in such good, but conglomeration in industry pertelevisian in indonesia has not been be improved.Political and economic became the reason for the main regulations broadcasting in indonesia has not been capable of being applied as in europe and the united states.
\end{abstract}

Keywords: Media, Television, Industry Media, Regulations, Political and Economic

How to Cite: Subhan, A.B., (2017), Peran Stasiun Televisi dalam Pengembangan Demokrasi, Ekonomi dan Politik di Indonesia, SIMBOLIKA, 3 (1): 98-105 


\section{PENDAHULUAN}

Media elektronik seperti radio dan televisi awalnya beroperasi dalam domain badan usaha milik negara. Hal ini terkait dengan pandangan kuno bahwa gelombang radio terbatas dan mahalnya biaya pengoparasian sebuah stasiun penyiaran. Sebagai contoh The British Broadcasting Corporation (BBC) didirikan atas dasar pertimbangan bahwa frekuensi radio adalah sumber daya alam yang terbatas sehingga harus digunakan secara hati - hati untuk kepentingan nasional dan mencegah dari adanya penggunaan yang berlebihan.

Dalam menjalankan usahanya, media atau pemilik media bersinggungan dengan kekuasaan. Para pemilik media kerap sebagai elite-elite bisnis industri yang berhubungan erat dengan para elite pemegang kekuasaan. Bisnis mereka kerap terkait dengan kebijakan elite kekuasaan.

Mengakibatkan "politik dagang" para pemilik media yang ikut melestarikan status quo kekuasaan para tokoh politik yang menjadi rekanan mereka. Jika memang demikian, kekuasaan pemilik media, meski secara etik dibatasi dan secara normatif disangkal, bukan saja memberi pengaruh pada konten media, namun juga memberikan implikasi logis kepada masyarakat selaku audience.

Adapun permasalahan yang dikaji dalam tulisan ini adalah bagaimana perkembangan kepemilikan media berdasarkan perspektif ekonomi dan politik media di Indonesia saat ini

Hal ini perlu dilakukan mengingat banyaknya institusi yang melaksanakan kegiatan yang berkaitan dengan sikap kritis terhadap media namun dengan pemahaman terhadap permasalahan maupun pemahaman terhadap konsep media yang berbeda-beda. Tingginya frekuensi kegiatan tersebut merupakan indikasi bahwa masalah media dan khalayaknya di Indonesia telah direspon dalam berbagai bentuk oleh kelompok- kelompok di masyarakat entah itu berupa lembaga swadaya masyarakat, perguruan tinggi, lembaga negara, sekolah-sekolah, dan sebagainya. Untuk memudahkan penelusuran, penelitian ini lebih fokus pada perkembangan media televisi di Indonesia tahun 2017.

\section{PEMBAHASAN}

Menurut Effendy (1989:361), television atau televisi merupakan media komunikasi jarak jauh dengan penayangan gambar dan pendengaran suara, baik melalui kawat maupun secara elektromagnetik kawat.

Televisi merupakan salah satu proses komunikasi media massa (mass media communication). Penyelenggaraan siaran merupakan komunikator sedangkan khalayak merupakan komunikan. Isi pesan televisi tersaji dalam bentuk informasi audio-visual gerak dan sinkron. Sasaran khalayak bisa bersifat local, regional, dan internasional. Televisi merupakan media komunikasi massa yang sangat kuat mempengaruhi pemirsa secara psikologis (Kuswandi, 1996: 124).

Terpaan media atau media exposure menurut Rosengren (1974: 271), adalah penggunaan media terdiri dari jumlah waktu yang digunakan dalam berbagai media, jenis isi media, media yang dikonsumsi atau dengan media secara keseluruhan (Rakhmat, 2004:66). Selain itu, terpaan media dapat diukur melalui frekuensi, durasi, dan atensi dari individu.

Secara definitif, politik ekonomi itu sendiri diartikan sebagai kajian terhadap relasi-relasi sosial, khususnya hubunganhubungan kekuasaan, yang secara mutual membentuk produksi, konsumsi, dan distribusi terhadap sumber-sumber ekonomi yang ada (Mosco, 2010: 25). Dalam konteks ekonomi politik komunikasi produk-produk komunikasi tersebut seperti surat kabar, video, films, buku-buku dan khalayak. Dengan demikian, definisi itu memberikan seperangkat dasar kategori yang membedakan fungsi dan beragamnnya tipe konsumsi seperti 
penonton film, penonton televisi, pembaca surat kabar, pendengar radio dan sebagainya. Ekonomi politik komunikasi (media) cenderung memusatkan perhatian pada seperangkat relasi-relasi sosial yang terorganisasi di seputar kekuasaan atau kemampuan mengontrol orang lain, prosesprosesnya dan hal lain bahkan di dalam hal menghadapi resistensi.

Media memiliki peran penting dalam kehidupan sosial dan kehidupan bernegara. McQuail (2002: 66) dalam bukunya "Mass Communication Theories" dalam Subiakto dan Ida (2012) mengatakan bahwa setidaknya ada enam perspektif dalam melihat peran media. Pertama, media massa dipandang sebagai window on events and experience. Media dipandang sebagai jendela yang memungkinkan khalayak "melihat" apa yang sedang terjadi di luar sana ataupun pada diri mereka sendiri. Kedua, media juga sering dianggap sebagai a mirror of events in society and the world, implying a faithful reflection. Yaitu, cermin berbagai peristiwa yang ada di masyarakat dan dunia, yang merefleksikan apa adanya. Ketiga, memandang media massa sebagai filter atau gatekeeper yang menyeleksi berbagai hal untuk diberi perhatian atau tidak. Keempat, media massa acap kali pula dipandang sebagai guide, penunjuk jalan atau interpreter, yang menerjemahkan dan menunjukkan arah atas berbagai ketidakpastian atau alternatif yang beragam. Adapun kelima, melihat media massa sebagai forum untuk merepresentasikan berbagai informasi dan ide-ide kepada khalayak, sehingga memungkinkan terjadinya tanggapan dan umpan balik. Terakhir, keenam, media massa sebagai interlocutor, yang tidak hanya sekadar tempat berlalu lalangnya informasi, tetapi juga partner komunikasi yang memungkinkan terjadinya komunikasi yang interaktif.

Beberapa jenis media massa antara lain televisi, radio, majalah, koran, dan juga internet. Dalam keseharian masyarakat
Indonesia, televisi tetap menjadi media yang paling besar pengaruhnya karena mudah diakses dan memiliki jangkauan yang luas. Bahkan menurut survey MarkPlus pada tahun 2014, televisi masih menempati peringkat pertama sebagai "Most Frequency Accesed Media" di Indonesia.

Secara harafiah, televisi berasal dari kata tele (jauh) dan vision (pandangan), dapat diartikan "melihat sesuatu dari jarak jauh". Televisi sebagai suatu alat penyampaian informasi komunikator dari kepada komunikan, merupakan salah satu bagian dari sebuah sistem yang besar dan kompleks. Alat ini akan berfungsi dengan baik apabila ditempatkan dalam sebuah sistem yang saling bekerja sesuai fungsinya. Sistem ini disebut sebagai sistem penyiaran televisi yang meliputi: sistem produksi (pesan), pemancaran gelombang dan pesawat televisi itu sendiri sebagai media penerima siaran.

Di Indonesia, siaran televisi pertama kali ditayangkan pada tanggal 17 Agustus 1962 yaitu bertepatan dengan peringatan Hari Kemerdekaan Republik Indonesia yang ke XVII. Pada saat itu, siaran hanya berlangsung mulai pukul 07.30 hingga pukul 11.02 WIB untuk meliput upacara peringatan hari Proklamasi di Istana Negara. Namun yang menjadi tonggak Televisi Republik Indonesia (TVRI) adalah ketika Indonesia menjadi tuan rumah Asian Games ke IV di Stadion Utama Senayan. Dengan adanya perhelatan tersebut maka siaran televisi secara kontinyu dimulai sejak tanggal 24 Agustus 1962 dan mampu menjangkau seluruh dua puluh tujuh propinsi yang ada pada waktu itu.

Sebagai satu-satunya stasiun televisi di Indonesia, TVRI mampu menjangkau wilayah nusantara hingga pelosok dengan menggunakan satelit komunikasi ruang angkasa kemudian berperan sebagai corong pemerintah kepada rakyat. Sebelum tahun 1990an, TVRI menjadi single source information bagi masyarakat dan tidak dipungkiri bahwa kemudian timbul upaya 
media ini dijadikan sebagai media propaganda kekuasaan. Seiring dengan kemajuan demokrasi dan kebebasan untuk berekspresi, pada tahun 1989 pemerintah mulai membuka kran ijin untuk didirikannya televisi swasta. Tepatnya tanggal 24 Agustus 1989 Rajawali Citra Televisi atau RCTI mulai siaran untuk pertama kalinya. Siaran pada waktu itu hanya mampu diterima dalam ruang lingkup yang terbatas yaitu wilayah Jabodetabek (Jakarta, Bogor, Depok, Tangerang, dan Bekasi) saja kemudian daerah lain memanfaatkan decoder untuk merelay siarannya.

Setelah RCTI kemudian disusul berurutan oleh Surya Citra Televisi (SCTV) pada tahun 1990 dan Televisi Pendidikan Indonesia (TPI) pada tahun 1991. Siaran nasional RCTI dan SCTV baru dimulai tahun 1993 kemudian pada tahun 1994 berdiri ANTeve dan Indosiar. Hingga saat ini tercatat ada 11dan beberapa stasiun televisi lokal yang mengudara secara nasional, selain stasiun tersebut di atas ada Trans TV, Global TV, Lativi, Metro Tv dan TV7 dan yang lainlainnya.

Sejak abad ke 20, kepentingan kapital telah menentukan arah tumbuhnya media, bahkan besar-kuatnya media. Pemilik media adalah para "businessman"; mereka merupakan pemilik modal yang mendirikan atau turut mendirikan usaha media dan berupaya untuk mencari keuntungan ekonomi melalui usahanya itu. Struktur organisasi media menjadi berkaitan dengan sistem ekonomi kapitalis yang membawa tujuan bisnis kompetitif dari pemilik industri media.

Dalam menjalankan usahanya, media atau pemilik media bersinggungan dengan kekuasaan. Para pemilik media kerap ditemukan sebagai elit-elit bisnis industri yang berhubungan erat dengan para elit pemegang kekuasaan. Bisnis mereka kerap terkait dengan kebijakan elite kekuasaan. Hal itu mengakibatkan "politik dagang" para pemilik media dituding ikut melestarikan status quo kekuasaan para tokoh politik yang menjadi rekanan mereka.

Seiring dengan terjadinya revolusi teknologi penyiaran dan informasi, industri media terbentuk dan menjadi besar dengan cara kepemilikan saham, penggabungan dalam joint-venture, pembentukan kerja sama, atau pendirian kartel komunikasi raksasa yang memiliki puluhan bahkan ratusan media. (Saverin dan Tankard, 2007). Lebih lanjut, Saverin dan Tankard mengatakan fenomena tersebut bukanlah semata-mata fenomena bisnis melainkan fenomena ekonomi-politik yang melibatkan kekuasaan. Kepemilikan media, bukan hanya berurusan dengan persoalan produk, tetapi berkaitan juga dengan bagaimana lanskap sosial, citraan, berita, pesan, dan kata-kata dikontrol dan disosialisasikan kepada publik (masyarakat). Contoh dalam korporasi media saat ini, khususnya televisi, di Indonesia seperti PT. MNC Group, PT. Trans Corp, dan lain sebagainya. Jaringan televisi MNC (Media Nusantara Citra) merupakan yang terbesar di Indonesia menaungi stasiun televisi seperti RCTI, MNC TV, dan Global TV. Sementara itu, RCTI (Rajawali Citra Televisi) adalah stasiun televisi swasta pertama yang mulai mengudara pada bulan Agustus 1989. RCTI dengan cepat menjadi televisi swasta terbesar karena didukung oleh pemerintahan saat itu Presiden Soeharto. Selama orde baru, bisnis media terkonsentrasi pada segelintir pelaku bisnis dan aktor politik yang mempunyai akses kuat ke lingkaran kekuasaan.

Dalam pendekatan ekonomi politik, kepemilikan media (media ownership) mempunyai arti penting untuk melihat peran, ideologi, konten media, dan efek yang ditimbulkan media kepada masyarakat. Karena itu pertanyaan-pertanyaan mengenai "apakah perbedaan pemilik media akan juga berarti adanya perbedaan pada konten media?" atau "apakah perbedaan pemilik media dapat memberikan implikasi yang berbeda pula kepada masyarakat 
selaku audience media?" menjadi sangat relevan.

Dewasa ini kecenderungan industri media sebagai alat kapitalisme menjadi semakin nyata. Bentuknya menjadi semakin menggurita, menjangkau ke mana-mana, cenderung ingin memonopoli dan bahkan melintasi batas negara. Tetapi kontrol pemilikannya justru makin terkonsentrasi hanya pada beberapa orang saja. Dalam menjelaskan fenomena tersebut Peter Gollding dan Graham Murdoch mengatakan "Media as a political and economic vehicle, tend to be controlled by conglomerates and media barons who are becoming fewer in number but through acquisition, controlled the larger part of the world's mass media and mass communication" (2000: 71). Menurut Feintuck, regulasi penyiaraan mengatur tiga hal yakni struktur, tingkah laku, dan isi. Regulasi struktur (structural regulation) berisi polapola kepemilikan media oleh pasar, regulasi tingkah laku (behavioural regulation) dimaksudkan untuk mengatur tata-laksana penggunaan properti dalam kaitannya dengan kompetitor, dan regulasi isi (content regulation) yang menjadi batasan material siaran yang boleh dan tidak untuk disiarkan.

Pada dasarnya kebijakan soal pembatasan Monopoli, Konglomerasi, dan Kepemilikan Silang (Media Penyiaran) sesungguhnya telah diatur dalam peraturan hukum, yakni UU Penyiaran nomor 32 tahun 2002 ayat 1 , pasal 18. Di sana disebutkan: "Pemusatan kepemilikan dan penguasaan lembaga penyiaran swasta oleh satu orang atau satu badan hukum, baik di satu wilayah siar maupun beberapa wilayah siar, dibatasi."

Selanjutnya Peraturan Pemerintah nomor 50 tahun 2005 tentang Penyelenggaraan Penyiaran Lembaga Penyiaran Swasta menyebutkan tentang pembatasan kepemilikan dan penguasaan atas jasa penyiaran radio dan televisi dikatakan:Pasal 311) Pemusatan kepemilikan dan penguasaan Lembaga
Penyiaran Swasta jasa penyiaran radio oleh 1 (satu) orang atau 1 (satu) badan hukum, baik di satu wilayah siaran maupun di beberapa wilayah siaran, di seluruh wilayah Indonesia dibatasi sebagai berikut: 1) 1 (satu) badan hukum hanya boleh memiliki 1 (satu) izin penyelenggaraan penyiaran jasa penyiaran radio; 2). Paling banyak memiliki saham sebesar $100 \%$ (seratus perseratus) pada badan hukum ke-1 (kesatu) sampai dengan ke-7 (ketujuh); 3) Paling banyak memiliki saham sebesar $49 \%$ (empat puluh sembilan perseratus) pada badan hukum ke-8 (kedelapan) sampai dengan ke-14 (keempat belas); 4) Paling banyak memiliki saham sebesar $20 \%$ (dua puluh perseratus) pada badan hukum ke-15 (kelima belas) sampai dengan ke-21 (kedua puluh satu); 5) Paling banyak memiliki saham sebesar 5\% (lima perseratus) pada badan hukum ke-22 (ke dua puluh dua) dan seterusnya); 6) Badan hukum sebagaimana dimaksud pada huruf $b$, huruf $c$, huruf $d$, dan huruf e, berlokasi di beberapa wilayah kabupaten/kota yang tersebar di seluruh wilayah Indonesia.

Pengecualian terhadap ketentuan sebagaimana dimaksud pada ayat (1) huruf c, huruf d, dan huruf e, memungkinkan kepemilikan saham sebesar 100\% (seratus perseratus) untuk Lembaga Penyiaran Swasta jasa penyiaran radio yang berada di daerah perbatasan wilayah nasional dan/atau daerah terpencil.2) Kepemilikan1) Kepemilikan badan hukum sebagaimana dimaksud pada ayat (1) berupa saham yang dimiliki oleh paling sedikit 2 (dua) orang sesuai dengan ketentuan peraturan perundang-undangan yang berlaku.2) Ketentuan sebagaimana dimaksud pada ayat (1) dapat ditinjau kembali untuk disesuaikan dengan perkembangan teknologi dan kebutuhan informasi masyarakat.

Jasa Penyiaran Televisi, Pasal 321) Pemusatan kepemilikan dan penguasaan Lembaga Penyiaran Swasta jasa penyiaran televisi oleh 1 (satu) orang atau 1 (satu) badan 
hukum, baik di satu wilayah siaran maupun di beberapa wilayah siaran, di seluruh wilayah Indonesia dibatasi sebagai berikut: 1) 1 (satu) badan hukum paling banyak memiliki 2 (dua) izin penyelenggaraan penyiaran jasa penyiaran televisi, yang berlokasi di 2 (dua) provinsi yang berbeda; 2) Paling banyak memiliki saham sebesar $100 \%$ (seratus perseratus) pada badan hukum ke-1 (kesatu); 3) Paling banyak memiliki saham sebesar $49 \%$ (empat puluh sembilan perseratus) pada badan hukum ke-2 (kedua); 4) Paling banyak memiliki saham sebesar $20 \%$ (dua puluh perseratus) pada badan hukum ke-3 (ketiga); 5) Paling banyak memiliki saham sebesar $5 \%$ (lima perseratus) pada badan hukum ke-4. (keempat) dan seterusnya;

Badan hukum sebagaimana dimaksud pada huruf $b$, huruf c, huruf $d$, dan huruf e, berlokasi di beberapa wilayah provinsi yang tersebar di seluruh wilayah Indonesia. 2) Pengecualian terhadap ketentuan sebagaimana dimaksud pada ayat (1) huruf c, huruf d, dan huruf e, memungkinkan kepemilikan saham lebih dari 49\% (empat puluh sembilan perseratus) dan paling banyak 90\% (sembilan puluh perseratus) pada badan hukum ke-2 (kedua) dan seterusnya hanya untuk Lembaga Penyiaran Swasta yang telah mengoperasikan sampai dengan jumlah stasiun relai yang dimilikinya sebelum ditetapkannya Peraturan Pemerintah ini. 3) Kepemilikan 4) Kepemilikan Lembaga Penyiaran Swasta sebagaimana dimaksud pada ayat (1) berupa saham yang dimiliki oleh paling sedikit 2 (dua) orang sesuai dengan ketentuan peraturan perundang-undangan yang berlaku.5) Ketentuan sebagaimana dimaksud pada ayat (1) dapat ditinjau kembali untuk disesuaikan dengan perkembangan teknologi dan kebutuhan informasi masyarakat.

Namun UU yang mengatur cross ownership ini ditentang bahkan mendapat penolakan keras dari pemilik media dan praktisi. Mereka bergabung dalam berbagai organisasi, di antaranya Asosiasi Televisi Seluruh Indonesia (ATVSI), Persatuan Radio Siaran Swasta Nasional Indonesia (PRSSNI), serta Masyarakat Pers dan Penyiaran Indonesia (MPPI). Dasar dari penolakan terhadap larangan cross ownership ini dilakukan atas nama kebebasan pers, revolusi teknologi informasi dan wacana demokrasi yang sedang dibangun Indonesia.

Sekilas alasan penolakan pemilik media dan praktisi di atas tampak rasional dan sulit terbantahkan, terutama untuk alasan kebebasan pers. Namun tampaknya penolakan itu bukanlah semata-mata keinginan untuk mendapatkan kebebasan berusaha seiring dengan makna kebebasan pers. Namun, juga ada alasan lain, yaitu bagaimana pemilik media dengan kekuatan modalnya melalui free trade memperoleh keuntungan yang sebesarbesar dari bisnis ini.

Di Indonesia, peraturan hukum tentang anti monopoli, pemusatan, dan kepemilikan silang media penyiaran sudah ada dan jelas berlaku sejak diundangkan, namun dalam praktiknya hingga saat ini, indsutri media penyiaran masih dikuasai kelompok tertentu. Dengan kata lain, penegakan hukum (law inforcement) tidak berjalan dengan baik, dan "kebijakan" penegakan hukum inilah yang perlu diprioritaskan oleh pemerintah dalam rangka menciptakan industri penyiaran yang demokratis. Dalam sistem demokrasi, menurut Siregar (2008: 40), regulasi terhadap media pada dasarnya dipilah menjadi dua bagian besar, yakni media yang tidak menggunakan ranah publik (public domain) dan media yang menggunakan ranah publik.Media yang tidak menggunakan ranah publik, misalnya, buku, majalah, suratkabar ataupun film (kecuali jika disiarkan melalui tv) maka regulasinya menggunakan prinsip selfregulatory. Dalam rentang masa 20 tahun, dari 50 media telah berada di bawah lima konsentrasi media. Melalui ulasan Bagdikian yang kemudian menjadi kritik klasik bagi 
analisis korporasi media, terungkap bahwa gejala tersebut akhirnya menjadi fenomena global yang disinyalir merupakan sisi gelap dari kebebasan pers. Liberalisasi media takterkendali yang bersinergi dengan pasar bebas akhirnya menciptakan pemusatan kepemilikan media hanya pada segelintir kelompok tertentu yang menguasai modal.

Untuk Indonesia, regulatornya adalah Komisi Penyiaran Indonesia (KPI) yang berhubungan dengan isi, dan Pemerintah, dalam hal ini Departemen Komunikasi dan Informatika (Depkominfo), yang berhubungan dengan penggunaan frekuensi dan pemberian izin penyiaran (Siregar, 2008: 40).

Menurut pandangan saya, model penataan industri penyiaran di Eropa cocok diterapkan di Indonesia. Hal ini berkaca dari kondisi saat ini, dimana industri penyiaraan (televisi) di Indonesia hanya dikuasai oleh segelintir orang saja. Misalnya MNC Group yang meliputi RCTI, Global TV, dan MNC TV dikuasai oleh Hary Tanoesoedibjo. Dampaknya pemberitaan yang disampaikan oleh tiga stasiun televisi tersebut seringkali tidak berpihak pada kepentingan publik. Dalam banyak kasus, justru kepentingan owner-lah yang lebih diutamakan. Sebagai contoh, melalui program Kuis Kebangsaan di RCTI, pemilik media yang juga seorang politisi memanfaatkan saluran publik untuk mengkampanyekan dirinya agar dipilih orang masyaraat pada saat Pemilu.

Dalam teori komunikasi massa, hal tersebut dinamakan teori agenda setting. Teori agenda setting berangkat dari asumsi "menciptakan apa yang menurut publik dianggap penting." Media menata (mensetting) sebuah agenda terhadap isu tertentu sehingga isu itu dianggap penting oleh publik yang salah satunya karena isu tersebut berhubungan dengan kepentingan publik, baik secara langsung atau tidak. Caranya, media dapat menampilkan isu-isu itu secara terus menerus dengan memberikan ruang dan waktu bagi publik untuk mengkonsumsinya, sehingga publik sadar atau tahu akan isu-isu tersebut, kemudian publik menganggapnya penting dan meyakininya. Sebetulnya, dengan kata lain, isu yang dianggap publik penting pada dasarnya adalah karena media menganggapnya penting.

Maka kekuasaan pemilik media, meski secara etik dibatasi dan secara normatif disangkal, bukan saja memberi pengaruh pada konten media, namun juga memberikan implikasi logis kepada masyarakat selaku audience. Pemberitaan media menjadi tidak bebas lagi; muatannya kerap memperhitungkan aspek pasar dan politik. Produk pemberitaan menjadi margin komoditas laba ekonomi sekaligus margin kepentingan politik. Hal itu, pada banyak kasus, telah mereduksi kemandirian institusi media. Akibatnya, terjadi kasus-kasus dimana liputan media harus berhadapan dengan kepentingan politik dan bisnis. Tematema liputan disesuaikan dengan orientasi tersebut.

Dampak lainnya ialah perubahan arah pemberitaan. Area pemberitaan "hard journalism" berubah jadi "soft journalism". Kisah-kisah soft news danhuman interest menjadi buruan wartawan. Liputan politik, seperti korupsi dan manipulasi serta nepotisme, menjadi fleksibel dan adaptabel. Berita-berita tersebut tidak segera atau bahkan terkadang tidak dapat disiarkan. Tapi, kerap dihambat, difilter, diatur, atau dikontrol.

Di Indonesia, pengaruh media berkembang sejak reformasi pada tahun 1998. Perkembangan yang signifikan adalah dipertegasnya kebebasan pers dalam konstitusi (UUD 1945) dan Undang-undang Pers, serta semakin kokohnya liberalisasi ekonomi. Kebebasan atau liberalisasi media juga memberikan keleluasaan dalam pemilikan media yang oleh pemodal kesempatan tersebut bergegas dimanfaatkan karena menjadi bagian dari strategi bisnis yang sangat menguntungkan. 


\section{SIMPULAN}

Para pekerja media itu tidak mengidahkan peraturan dari KPI terkait Pedoman Perilaku Penyiaran dan Standar Program Siaran (P3-SPS). Pada pasal 11 jelas mengatakan bahwa, lembaga penyiaran wajib memperhatikan kemanfaatan dan perlindungan untuk kepentingan publik. Kemudian dijelaskan lagi dalam pasal 13 ayat 2 bahwa program siaran tentang permasalahan kehidupan pribadi tidak boleh menjadi materi yang ditampilkan dan/atau disajikan dalam seluruh isi mata acara, kecuali kepentingan publik. Beberapa media kerap menampilkan tayangan yang nyatanya memiliki manfaat kecil bagi masyarakat namun memiliki porsi besar untuk ditayangkan di stasiun televisi terkait khusunya. Kini lembaga pers/media hanya berperan sebagai instansi bisnis. Hanya dengan bisnis yang baik dan pemasukan modal yang banyak, mereka akan "tunduk" dengan pemilik modal. Tanpa memperhatikan kenyamanan dan faedah yang dapat diambil oleh masyarakat akan konten yang ditayangkan. Jadi dapat disimpulkan, kebebasan pers yang telah diperjuangkan secara mati-matian dari masa ke masa tidak dihargai secara full saat ini. Kebebasan pers saat ini lebih dijadikan sebagai bentuk "investasi bisnis". Semakin besar biaya yang dikeluarkan pemilik modal dan sponsor, maka semakin besar pula frekuensi siaran yang ditampilkan. Mereka seakan lupa betapa pedihnya "dijajah informasi" oleh pemerintah. Namun kini, setelah masa tersebut sirna, kebebasan pers malah tidak digunakan sebaik mungkin. Kebebasan pers saat ini seperti berjalan ditempat. Sama layaknya masa orde baru yang penuh dengan pembredelan oleh pemerintah. Kini hanya berganti nama menjadi pembredelan oleh pemilik modal dan sponsor bisnis.

\section{DAFTAR PUSTAKA}

Istanto, F.H. (1999)., Peran Televisi Dalam Masyarakat Citraan Dewasa Ini Sejarah, Perkembangan Dan Pengaruhnya. NIRMANA Vol. 1, No. 2, Juli 1999 Jurnal Jurusan Desain Komunikasi Visual, Fakultas Seni dan Desain Universitas Kristen Petra.Yogyakarta

McQuail, (1987), Teori Komunikasi Massa Suatu Pengantar. Erlangga: Jakarta

Milana, R., (2010). Kepemilikan Media: Perspektif Ekonomi dan Politik. [Online] diakses pada tanggal 16 Januari 2015 at: http://media.kompasiana.com/mainstreammedia/2010/06/21/kepemilikan-mediaperspektif-ekonomi-politik-173487.html

Subiakto, H. (2005), Prinsip Pengaturan Kepemilikan Media Penyiaran. [Online] diakses pada tanggal 16 Januari 2015 at: https://mejikubirubiru.wordpress.com/2014 $\angle 03 / 23 /$ prinsip-pengaturan-kepemilikanmedia-penyiaran/

Subiakto, H., \& Rachmah I., (2012). Komunikasi Politik, Media, dan Demokrasi. Jakarta: Kencana.

Suryo, R., (1996). Televisi Sebagai Fungsi Media Komunikasi Massa. Yogyakarta. Bahan Diktat Pendidikan Audio Visual Reguler LPM MANDIRI Yogyakarta

Yusuf, I.A., (2010). Pentingnya Regulasi Terhadap Monopoli dan Konglorasi Media. [Online] diakses pada tanggal 16 Januari 2015 at: https://bincangmedia.wordpress.com/2010/ 05/31/pentingnya-regulasi-atas-

konglomerasi-dan-monopoli-kepemilikianmedia/

Manfaat - (2011). Menakar Biaya dan Ekonomi atas Pembatasan Monopoli, Konglomerasi, dan Kepemilikan Silang Industri Media Penyiaran. [Online] diakses pada tanggal 16 Januari 2015 at: https://bincangmedia.wordpress.com/2011/ 05/03/menakar-biaya-dan-manfaatekonomi-atas-pembatasan-monopolikonglomerasi-dan-kepemilikan-silangindustri-media-penyiaran/ 